\title{
Correction to: Preface to the special issue on program comprehension
}

\author{
Janet Siegmund ${ }^{1} \cdot$ Chanchal K. Roy $^{2}$
}

Published online: 23 October 2021

(c) The Author(s) 2021

\section{Correction to: Empirical Software Engineering (2020) 25:2137-2139 https://doi.org/10.1007/s10664-020-09806-x}

The article "Preface to the special issue on program comprehension", written by Janet Siegmund and Chanchal K. Roy, was originally published Online First without Open Access. After publication in volume 25, issue 3, page 2137-2139 the author decided to opt for Open Choice and to make the article an Open Access publication. Therefore, the copyright of the article has been changed to (OThe Author(s) 2020 and the article is forthwith distributed under the terms of the Creative Commons Attribution 4.0 International License, which permits use, sharing, adaptation, distribution and reproduction in any medium or format, as long as you give appropriate credit to the original author(s) and the source, provide a link to the Creative Commons licence, and indicate if changes were made. The images or other third party material in this article are included in the article's Creative Commons licence, unless indicated otherwise in a credit line to the material. If material is not included in the article's Creative Commons licence and your intended use is not permitted by statutory regulation or exceeds the permitted use, you will need to obtain permission directly from the copyright holder. To view a copy of this licence, visit http://creativecommons.org/licenses/by/4.0/. Open Access funding enabled and organized by Projekt DEAL.

Open Access This article is licensed under a Creative Commons Attribution 4.0 International License, which permits use, sharing, adaptation, distribution and reproduction in any medium or format, as long as you give appropriate credit to the original author(s) and the source, provide a link to the Creative Commons licence, and indicate if changes were made. The images or other third party material in this article are included in the article's Creative Commons licence, unless indicated otherwise in a credit line to the material. If material is not included in the article's Creative Commons licence and your intended use is not

The original article can be found online at https://doi.org/10.1007/s10664-020-09806-x.

Janet Siegmund

siegmunj@fim.uni-passau.de

1 Chemnitz University of Technology, Chemnitz, Germany

2 Department of Computer Science, University of Saskatchewan, Saskatoon, Canada 
permitted by statutory regulation or exceeds the permitted use, you will need to obtain permission directly from the copyright holder. To view a copy of this licence, visit http://creativecommons.org/licenses/by/4.0/.

Publisher's Note Springer Nature remains neutral with regard to jurisdictional claims in published maps and institutional affiliations. 